Food Hygiene Dept., Chemistry and Food Deficiency, Dept. Pathology Dept. AHRI

Dokki, Giza.

\title{
SOME PHARMACOLOGICAL AND PATHOLOGICAL STUDIES ON ALLIUM SATIVUM (GARLIC)
}

(With 3 Tables and 8 Figures)

\author{
By \\ M.A. EL-SHATER; HANAN M.S. SOBBHY \\ and GEHAN J. SHEHAB
}

(Received at 24/12/1997)

بعض الدراسات الفارماكولوجبه و الباثولوجيه على الثوم

محمد الشاطر ، حنان محمد صبحى ، جيهان شهاب

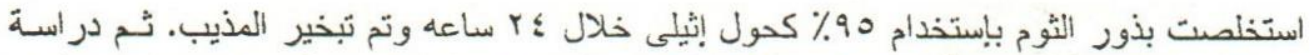

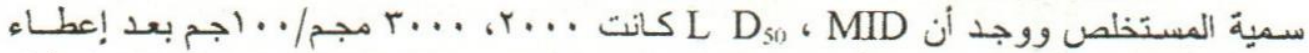

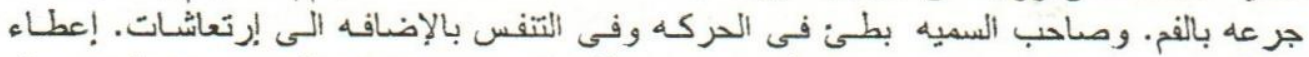

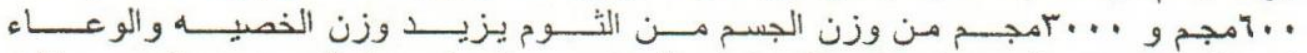

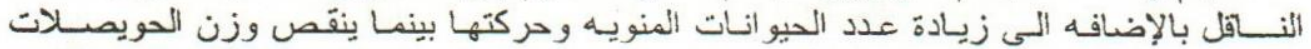

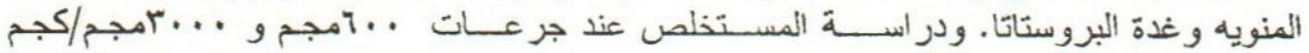

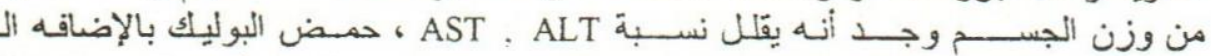

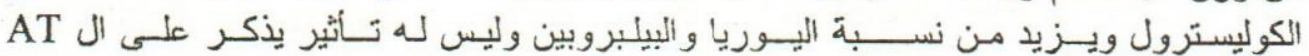

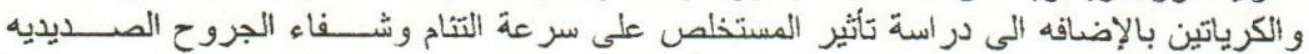

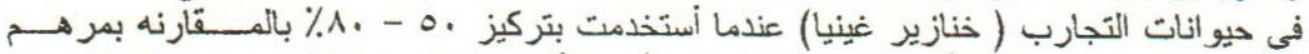

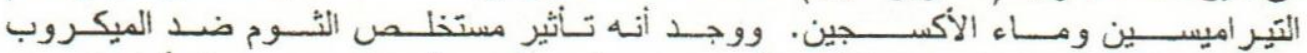

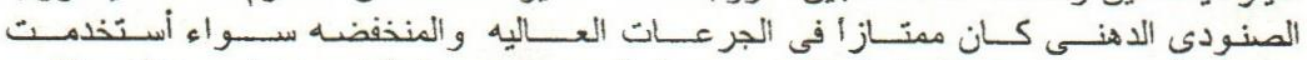

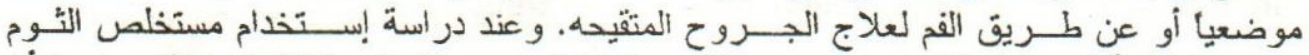

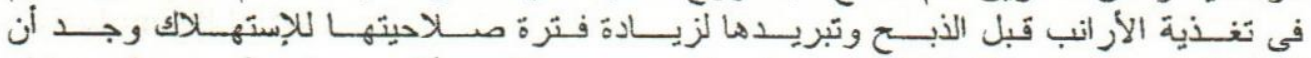

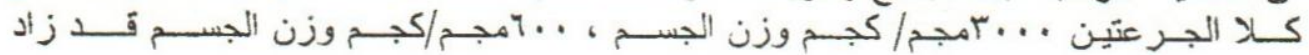




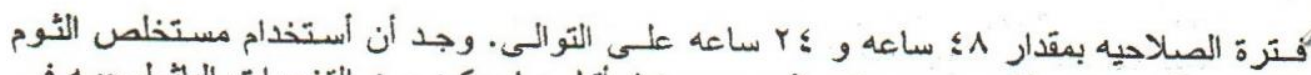

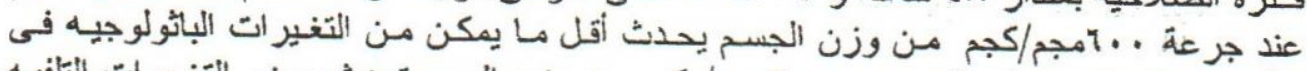

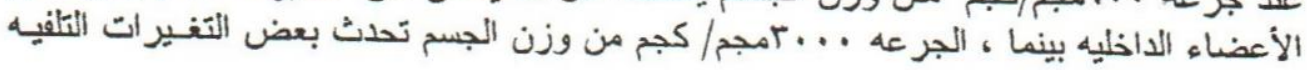

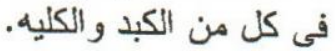

\section{SUMMARY}

Seeds of Allium sativum were extracted with $95 \%$ ethanol for 24 hours, then the solvent was evaporated. Toxicity studies using this extract showed that minimum lethal dose (MLD) and LD $_{s 0}$ were 2000 and $3000 \mathrm{mg} / 100 \mathrm{~g}$ b.wt., respectively after oral administration in mice. Toxicity.was accompanied by sluggish movements and respiration as well as some tremblings. Oral administration of 600 and $3000 \mathrm{mg} / \mathrm{kg}$ b.wt. Allium sativum extract significantly increased weight of testis and epididymis, while decreased the weight of seminal vesicles and prostate gland. The number and motility percentage of the spermatozon were increased. The studied extract at doses of 600 and $3000 \mathrm{mg} / \mathrm{kg}$ b.wt. Significantly decreased level of alanine aminotransferase(ALT), aspartate aminotransferase (AST), uric acid \& cholesterol but significantly increased those of urea and bilirubin and had insignificant effect on alkaline phosphatase (AP) and creatinine.Moreover; in vivo studies revealed that the tested extract enhanced healing of surgically and pyogenically infected wounds in Guinea pigs when used as dressing in $50-80 \%$ solution extract as compared with terramycin ointment and Hydrogen peroxide solution $\left(\mathrm{H}_{2} \mathrm{O}_{2}\right)$. The antibacterial effect of garlic against Staphylococcus aureus (enterotoxogenic) was remarkable at both high and low dose of the extract (locally or systemic) in contaminated surgical wound. The use of garlic extract in feeding rabbits before slaughter and chilling for extending the shelf life of meat. The results showed that both the high dose $(3000 \mathrm{mg} / \mathrm{kg}$ b.wt.) and low dose $(600 \mathrm{mg} / \mathrm{kg} \mathrm{b.wt}$.) extended the shelf life of the rabbit chilled meat for $48 \mathrm{hr}$. and $24 \mathrm{hr}$. respectively. The use of garlic extract in a dose of $600 \mathrm{mg} / \mathrm{kg}$ b.wt. revealed minimal pathological changes in the internal organs, while a dose of $3000 \mathrm{mg} / \mathrm{kg}$ b.wt. revealed some degenerative change in both liver and kidneys as well as partial haemolysis of red blood cells (RBCs).

Key words: Allium sativum - Pharmacology - Pathology 


\section{INTRODUCTION}

Allium sativum (garlic) has become increasingly popular in recent years, not only because of its unique flavour but also because of its medicinal properties (Anussorn et al., 1979). Allium sativum is used in folk medicine as either or infusion or decoction or juice for treatment of many diseases. Several studies were carried out to find out scientific basis for garlic use in folk medicine. The antimicrobial properties of garlic have been known for a long time (Hanudin \& Djatnika, 1986; Rode et al., 1989 and Dalvi \& Salunkhe, 1993). However, the plant also possesses anticarcinogenic activity (Aboul Enein, 1986 and Dobrzanski \& Kuzminska, 1994), hypolipidemic (Bobboi et al., 1984; Anand \& Kochal, 1980; Sainai et al., 1979 and Chaudhuri et al., 1984). and reduces cholesterol level in the blood (Bhushan et al., 1979; Sharma \& Sharmas, 1979; Bakhsh and Ghughlta, 1985). Acute toxicity of the constituents of garlic is rare in humans but can be seen in farm animals (Dalvi \& Salunkhe, 1993). The use of garlic juice in ration will act as an antimycotic as well as antibacterial agent (Nafady et al., 1990). The aqeous garlic extract was screened for antibacterial activity against 9 clinical strains of Staphylococcus, E.coli, Proteus, Pseudomonas and Klebsiella. Garlic extract exhibit promising antibacterial activity against all strains except Klebsiella. (Singn and Shukla, 1984). Allitridin is an antibacterial and antiviral agent present in extracts of garlic (Lu - Yonghzi et al., 1994). The garlic extracts exhibited antibacterial effect against 7 enteric pathogenic bacteria (E.coli, Salmonella typhimurium, Salmonella havana, S. paratyphi, Shigella flexneri and Shigella dysentri (Mehrabian et al., 1992). The diallyl thiosulphinate (allicin), methyl allyl thiosulphinate and allyl methyl thiosulphinate from aqeous garlic clone show antibacterial effect against E.coli, Staph. aureus and also anticandida effect (Hughes and Lawson, 1991).

The present work was conducted to reveal toxicity, pharmacological, antibacterial, preservative and pathological effects of Allium sativum as they
still require more investigation.

\section{1) Animals :}

\section{MATERIAL and METHODS}

Mice: 25 mice $(20-30 \mathrm{~g})$

Rats: 30 mature male rats $(200-220 \mathrm{~g})$. Animalsfed on ordinary ration and water add-libtium. 
Rabbits: 51 mature normal New-Zealand rabbits $(1.5-2 \mathrm{~kg})$

\section{2) TEST PLANT:}

Animals were kept in sterilized metal cages.

Allium sativum seeds were cleaned, weighed $(250 \mathrm{gm})$ and cut to small pieces for extraction. The known weight was blended with ethyl alcohol $95 \%$ overnight, then filtered through two layers of muslin. The extract was collected and the solvents were completely evaporated under vacuum at room temperature by rotatory evaporator. The yield of extract was calculated

\section{A. PharmaCological aCtivity}

\section{Acute toxicity:}

$\mathrm{LD}_{s_{0}}$ of Allium sativum seed extract was determined as described by Kerber (1941). Five groups of five mice each weighing $20-25 \mathrm{~g}$ body weight were used. Different doses of Allium sativum extract $(350,450,550$ 650 and $750 \mathrm{mg} /$ mouse) were administered orally. Toxic symptoms and mortality rate were recorded and the $\mathrm{LD}_{50}$ of the tested extract was calculated.

II. The effect of Allium sativum extract on sexual organs and epididymal sperm character:

The effect of Allium sativum on sexual organs of male rat were assessed by spermatozoal examination. This was performed on 3 groups of 5 mature male Albino rats of $200-220 \mathrm{~g}$. The first group was kept as control whereas the second and third groups were given alcoholic extract in doses of 600 and $3000 \mathrm{mg} / \mathrm{kg} \mathrm{b.wt.,} \mathrm{respectively.} \mathrm{The} \mathrm{tested} \mathrm{extract} \mathrm{was} \mathrm{given} \mathrm{for} 65$ days (Hershberger et al., 1969). Thereafter; rats were sacrificed by decapitation. Testes, epididymis and accessory glands were dissected out, examined macroscopically and weighed. The number of epididymal sperms was counted as reported by Bearden and Fluquary (1980) where the number of sperms was multiplied by their dilution, warming and expressed in percentage. Sperm head abnormalities were determined microscopically.

\section{Biochemical analysis :}

Fifteen male albino rats weighing between $200-220 \mathrm{~g}$ were used. The rats were divided into three equal groups. The first group was kept as control. The second and third groups were administered orally 600 and 3000 $\mathrm{mg} / \mathrm{kg}$ b.wt. for 60 successive days. Blood samples were left to clot then centrifuged and the serum was separated for determination of Alanine transaminase (ALT), Aspartate transaminase (AST) and Alkaline- 
phosphatase (AP) according to (Reitman \& Frankel, 1957) and Roy (1970); Uric acid (Barham \& Trinder, 1972), Creatinine (Teger - Nilson, 1961); Cholesterol (Fredrickson et al., 1967) and Bilirubin (Walters et al., 1970).

\section{B. MICROBIOLOGICAL ASSAY}

\section{ANTIBACTERIAL EFFECT : (Amal, 1995).}

The antibacterial effect was studied in 5 groups of rabbits each consisting of 6 animals weighing about $2 \mathrm{~kg}$. The first and second groups were prophylacted by drinking the garlic aqueous extract for 7 successive days before experiment. The third and fourth groups were not prophylacted while the fifth group was kept as control (C). The experiment was carried out through created surgical wound in both thigh of the animals, then infected with Staphylococcus aureus. The wound was left for $48 \mathrm{hr}$. till pus formation; then third and fourth groups were treated locally with $80 \%$ of and $50 \%$ of garlic extract respectively. Fifth group was treated with $\mathrm{H}_{2} \mathrm{O}_{2}$ and terramycin ointment till healing occured. First and second groups were orally administered garlic extract at doses of 600 and $3000 \mathrm{mg} / \mathrm{kg} \mathrm{b}$.wt. in drinking water respectively.

\section{II- PRESERVATIVE EFFECT OF THE GARLIC:}

This effect was studied by giving 3 groups of rabbits $\left(D_{1}, D_{2}\right.$ and $\left.C\right)$,, each consisting of 7 animals garlic extract in drinking water for 7 successive days before slaughtering.

Groups $D_{1}$ and $D_{2}$ were given 600 and $3000 \mathrm{mg} / \mathrm{kg}$ b.wt. garlic extract $/ \mathrm{kg}$ b.wt. while group $\mathrm{C}$ was kept as control. After 7 days, rabbits were slaughtered, dressed, thoroughly washed and each animal was put in sterile polyethylene bag (after cutting into four quarters) and kept at refrigerated at. $2^{\circ} \mathrm{C}$. The tested and control samples were examined every 24 $\mathrm{hr}$. for 7 days for the following tests :

\section{MICROBIOLOGICAL COUNTS AND SENSORY TESTS}

The tested and control samples were examined every $24 \mathrm{hr}$ for 7 days for microbiological and sensory tests. The microbiological evaluation (Psychrophilic count, Mold and Yeast count and Enterobacteriacae count) were carried out according to APHA 1984. The sensory evaluation included $\mathrm{pH}$ value (AOAC 1980), total volatile base nitrogen (TVB-N FAO 1980) and boiling and roasting test. The mean value of the four quarter microbiological counts, $\mathrm{pH}$ value and TVB-N were recorded.

\section{PATHOlOGiCAL ASSAY}

The tested rats were subjected to pathological studies. Specimens 
from heart, liver, kidneys, spleen, intestines and testis were preserved in 10 $\%$ formaline buffer, processed routinely and sectioned at 4-5 $\mu$. The paraffin sections were stained with haematoxyline and eosin (Harris, 1989).

\section{RESULTS}

Toxicity experiments revealed that $\mathrm{LD}_{50}$ of Allium sativum in mice was $3000 \mathrm{mg} / 100 \mathrm{gm} \mathrm{b}$.wt. after its oral administration. The acute toxicity is characterized by sluggish movements and respiration and some tremblings.

Oral administration of garlic extract in doses of 600 and $3000 \mathrm{mg} / \mathrm{kg}$ b.wt. to mature rats for 65 days significantly increased weight of testis and epididymis as well as sperm cell count and motility percentage while it decreased the weight of seminal vesicles and prostate glands. The extract of Allium sativum significantly decreased activities of ALT and AST in serum of treated rats as compared with those of the control.

Garlic extract had insignificant effect on AP enzyme activity in serum treated rats (Table 2).

Results obtained indicated that administration of Allium sativum extract significantly increased urea and bilirubin concentration in serum of rats but decreased those of uric acid and cholesterol and had no effect on creatinine (Table 2).

\section{Microscopical Examination:}

The microscopical examination of rats of group I which received 600 $\mathrm{mg} / \mathrm{kg}$ of garlic revealed that there was slight congestion with few haemorrhagic spots on the internal organs. The liver and kidneys showed few focal areas of whitish discolouration. The intestine was slightly congested.

The microscopical examination of rats of group II which received higher dose of garlic (3000 mg/ kg b.wt.) revealed congestion and haemorrhage in the internal organs, with multiple areas of greyish white discolouration in both liver and kidneys. The intestine was slightly congested.

The histopathological examination of the internal organs from rats of group I showed slight congestion of the internal organs associated with few haemorrhagic spots. Few vacuolar and/or granular degeneration of some hepatocytes were seen. The kidneys showed few granular degeneration of the lining tubular epithelium as well as slight degeneration of the glomerular tuft capillaries. Examination of the testis revealed slight interstitial oedema. No changes could be observed in both spleen and heart. 
The microscopical examination of rats of group II which received high dose of garlic, revealed congestion and haemorrhage in liver with thickening of the portal area by fibroblasts. Granular and/or vacuolar degeneration of the hepatocytes with individual cell necrosis were seen. Few blood vessels showed partial haemolysis of red blood cells. (Fig. 1).

The kidneys revealed few interstitial haemorrhage with partial hemolysis of red blood cells (Fig.2). Moderate degeneration and necrosis of the lining tubular epithelium as well as some glomeruli showed hypercellularity of the glomerular tuft capillaries with few interstitial oedema.

The intestine showed congestion with slight haemorrhage in the submucosal layer with degeneration of some lining epithelium of the villi (Fig. 3). The spleen showed partial haemolysis of some red blood cells with haemosidrosis. The testis showed oedema and minimal degeneration of the spermatogenic cells lining the seminiferous tubules. No changes could be observed in the heart.

\section{DISCUSSION}

Allium sativum is an important vegetable extensively cultivated in many countries. It is used as food for human, added to food of some animals and as a remedy for some diseases as reported in folk medicine.

The current experiments were performed to study the toxic effect of bulbs of Allium sativum. Results showed that the minimum lethal dose (MLD) of the alcoholic extract was $2000 \mathrm{mg} / 100 \mathrm{gm} \mathrm{b}$.wt. $L_{50}$ of the studied extract was $3000 \mathrm{mg} / 100 \mathrm{gm}$ b.wt. These result indicate that alcoholic extract of the bulb of Allium sativum is safe. Besides, symptoms of acute toxicity of the extract in mice were relatively mild. This fact is confirmed by the use of the plant as food for human (Dalvi and Salunkhne, 1993) and in folk medicine (Baily, 1953 and Feo, 1993). No available literature could be collected on the toxicity of garlic except that reported by Dalvi and Salunkhne (1993) who observed that garlic is rare ly toxic in humans but its adverse reactions can be seen in farm animals after consumption of wild garlic. The tested extract of garlic at doses of 600 and $3000 \mathrm{mg} / \mathrm{kg}$ b.wt. for 65 successive days in male rats significantly increased the weight of testicular and accessory glands. sperm cell count and progressive motility but decreased the weight of prostate glands and percentage of abnormalities. No available literature could be traced on the 
effect of Allium sativum on fertility, except that recorded by El Bekairi et al. (1991) who found that aqueous extracts of Allium cepa increased the testicular and accessory glands weights and increased the sperm cell concentration; these results agree with our results because Allium sativum and Allium cepa belong to the same genus (Tackholm, 1974). These effects may be due to a direct effect on male reproductive organs or on androgenic hormones (El-Bekairi et al., 1991).

Allium sativum at the same doses caused significant decrease in ALT, AST activities, uric acid and cholesterol concentration; but significantly increased the urea and bilirubin concentration in serum. These results agree with those of Bhushan et al. (1979); Sharma and Sharma (1979); Bakhsh and Ghughtai (1985); El-Habbok et al. (1989) and Lonksy et al. (1993) who reported that garlic decreases the concentration of cholesterol. Abdo et al. (1983) found that chicken fed on garlic for 40 and 50 days of age had increased activity of alkaline phosphatase. However our results disagree with El-Habbok et al. (1989) who found that the ethanolic extract or fresh garlic decreased the alkaline phosphatase but the aspartate and alanine amino transferases were not affected in Japanese quil.

The antibacterial effect of garlic against Staph. aureus was studied in vivo. Figures. $(1,2)$ show that the garlic treatment either locally or systematically was better than the anctibatic methods of treatment.

The result recorded in (Table 3 ) and Figures $(3,4,5)$ stated the mean microbiological count $\left(\log _{10} / \mathrm{gm}\right)$, for psychrotrophic bacteria, mold \& yeast and Enterobacteriacae. At zero day (just after slaughter and preparation) the mean Enterobacteriacae count was $(<2)$ for tested samples $\left(D_{1}, D_{2}\right)$ while control samples were (2). The mean psychrotrophic count was relatively high in control sample compared with tested sample $D_{1}$ while $D_{2}$ was $<2$. After $72 \mathrm{hr}$. chilling preservation, the microbial loads were significantly increased in $\mathrm{D}_{1}$ and $\mathrm{D}_{2}$, as well as in control samples, the psychrotrophic count, mold $\&$ yeast and enterobacteriacae count, were 5.3, 4.3, 3.9 and 3.9, 2.8, 2.3 for $\mathrm{D}_{1}$ and $\mathrm{D}_{2}$ respectively. The same aforementioned means of microbiological count $\left(\log _{10} / g\right)$ were $5.5,4.8,4.6$ recorded for control samples. These results, reveal faster propagation of microbiological load in control sample compared with tested samples $\mathrm{D}_{1}$ and $\mathrm{D}_{2}$. Concerning the sensory test; the tested and control samples still fleshy (without noticeable deterioration criteria) till 48 hours chilling preservation as TVB-N mean (mg \%) for tested sample $D_{1}$ and $D_{2}$ were $(14,19)$ at $p H$ values $(6.09,6.08)$ and for control 
samples were (13) at $\mathrm{pH}$ value 6.1; still at safe limits.

The TVBN mean values became to be relatively noticeable by boiling \& roasting test at $72 \mathrm{hrs}$ for both control and $\mathrm{D}_{1}$ tested samples but retarded till 120 hours for $\mathrm{D}_{2}$ tested samples.

The control samples become obviously deteriorated (putrid) after 96 hours with mean microbiological count $\left(\log _{10}\right)$ for psychrotrophic, mold and yeast and enterobacteriacae counts were $(5.9,5.5,5.1)$ respectively. The mean TVB-N (mg \%) of control group was (24.0) at $\mathrm{pH}$ value 6.39.

The putrid odour of the tested sample $\mathrm{D}_{2}$ could be detected at the time 144 hours as TVB-N exceed the permissible limits for healthy human consumption recommended by ESS (1986) for rabbit. These results could be due to garlic feeding decreases the gut flora (Shashikanth et al. 1986); this consequently decrease the initial microflora containing carcass and leads to the retardation of spoilage criteria.

The pharmacological and clinical evidence concerning the antibiotic properties of garlic (A.sativum), and garlicin is reported to be the antibiotic agent from garlic (Koch, 1993). The antibacterial, antifungal effect and anticandidal effect of garlic was reported by, Hughes and Lawson (1991); Mehrabian et al., 1995 and Gandhi and Gnodekar, 1988).

These results of many authors may support the use of garlic extract feeding ration for good quality attributes chilled product.

Concerning the histopathological effects, the current study showed that the liver and kidneys of rats from group II had granular and/or vacuolar degeneration of the hepatocytes and some lining tubular epithelium of the kidneys associated with individual cell necrosis and few interstitial oedema were seen. Partial haemolysis of red blood cells was seen within the lumen of some blood vessels. These aforementioned observations coincided with that of Lincoln et al. (1992) who noticed that, haemolysis of some red blood cells and haemolytic anaemia were found after acute toxicity in cattle fed on garlic.

In this respect Dalvi and Salunkhne (1993) detected acute toxicity from the constituents in the form of haemolytic anaemia, jaundice, haemoglobinurea with kidney and liver damage. 


\section{REFERENCES}

Abdo, M.S.; Mansour, Soad, A.; EL-Nahla, Amal, M. (1983): Effect of some feed additives on blood constituents of growing Hubbard Chickens. Vet. Med. J., 31 (2), $221-31$.

Aboul Enein, A. (1986): Inhibition of tumor growth with possible immunity by Egyptian garlic Allium sativum extracts. Nahrung, 30 (2), 161 189.

Al-Bekairi, A.M.; Gureshi, S.; Shah, A.H. (1991): Toxicity studies on Allium cepa, its effect on estradiol treated mice and on epididymal spermatozoa. Fitoterapia, 62: 4, $301-306$.

Amal, A. Zaki. (1995): Pharmacological effects of Alliumcepa (onion) Extracts. Thesis (Mv.Sc) Cairo University.

Anand, M.P. and Kochar, A.S. (1980): Effect of garlic on lipid profile. Int.

Congr. Ser - Excerpto. Med., 502. (Intern. Med. pt. 2), 1255 - 7.

Anussorn-Nitisora-Nualchina; Vongratanastit, Thanomsri; Wuthi -

Uclomlert, Mansuang (1979): Pharmaceutical preparation of Allium sativum. Varasan Paesachasasthara, 6 (2) 31-8.

Baily, L.H.(1953): "The standard cycopedia of Horticulture. The Macmillan Co., ${ }^{\mathrm{N}} \mathrm{ew}$ York, Toranto London Vol. I, 247.

Bakhsh, Rasool and Ghughlta, M.I.D. (1985): Comparative study of onion and garlic on serum cholesterol, liver cholesterol, prothrombin time and fecal sterols excretion in male Albino rats. J. Chem. Soc. Pak., 7 (4), 285 - 8.

Barham, D. and Trinder, P. (1972): "Colorimetric determination of serum uric acid" Analyst, 97: 142 - 145.

Bearden, H. and Fhrquary, W. (1980): "Applied animal reproduction". Chapter 15, pp. 157 - 169, Missisppi state University, Reston publishing company, Inc.

Bhushan, S.; Sharma, S.P.; Singh, S.P.; Agrawal, S.; Indragan, A.; Seth, P. (1979): Effect of garlic on normal blood cholesterol level. Indian J. Physiol. Pharmacol., 23 (3), 211 - 14.

Bobboi, Amimu, Angus, Ti, K. T.; Joseph, P.K. (1984): Hypolipidemic effects of onion oil and garlic oil in ethanol - fed rats. Indian J. Biochem. Biophys. 21 (3), 211 - 3. 


\section{Assiut Vet. Med. J. Vol. 38 No. 76, January 1998}

Chaudhuri, B.N.; Mukherjee, S.K.; Mongia, S.S.; Chakravaity, S.K. (1984): Hypolipidemic effect of garlic and thyroid function. Biomed.

Biochem. Acta, 43 (7), 1041 - 3.

Dalvi-RR and Salumkhe-DK. (1993): An overview of medicinal and toxic properties of garlic. J. of Maharashtra - Agric. Univ., 18 :3, 378 381.

EL-Habbok-MME; Saleh-K; Arbid-MS; Hegazi-AG; Sofy-H. (1989): Influence of garlic (Allium sativum) L.) on some biological and biochemical changes in Japanese quil with special reference to its hypocholesterolemic activity. Archiv-Fur-Geflugelkunde., 53:2,73-79.

Feo, U.De; Senatore, F. and De-Feo, V. (1993): Medicinal plants and phytotherapy in Amalfitan. J. of Ethanopharmacology, 39: 1, 39 - 51. ESS (1986): Egyptian Standard Specification for Poultry and Rabbits., No. 1090.

Fredrikson, D.S.; Levi, R.L. and Less, R.S. (1967): "Determination of cholesterol" N. Engl. J. Med. 276: 148 - 156.

Gandhi-DN; Ghodekar - DR (1988): Antibacterial activity of garlic extract

against lactic acid bacteria and contaminants of fermented milks.

Indian - Journal of Dairy Science, 41; 4, 511 - 512; 9 .

Harris, H.E. (1989): Cited by carleton, M.A.; Drury, R.A.; Wallington.,

E.A. and Comerson, H. (1907): Carleton's histological technique. 4th

Ed. Oxford University press, New York, Torento.

Hamudin and Djatnika, I. (1986): The effect of some plant extracts on bacterial with (Pseudomonas solanacearum E.F. smith) growth in

Hershberger, L.G.; Hansen, D.M. and Hansen, L.D. (1969): "Effect of antifertility agents on male mice and rats as determined by a serial mating technique". Proc. Soc. Exp. Biol. Med., 131:667 - 669.

Hughes-BG and Lawson-LD (1991): Antimicrobial effect of Alium sativum

L. (garlic), Alium ampeloprasum L. (elephant garlic) and Alium cepal

L. (onion), garlic compounds and commercial garlic supplement products. Phytotherapy - Research. 5: 4, $154-158 ; 35$.

Kerber, G. (1941): Pharmakologische Methoden Zur Auffindung Von

Arzneimtteln und Gifter und Analyse rhuer wirkungs weise vor,

Kock-H.P (1993): Garlin- fact or fiction? The antibiotic substance from

garlic (Allium sativum L.). Phytotherapy - Research, 7: 4, 278; 29. 
Lanky - P.S; Schilcher-H (ed); Philipson-JD; Loew-D. (1993): Plants that lower cholesterol. Acta - Horticulturae, 332, 131 - 136.

Lincoln, S.D; Howell, M.E; Comus, J.J and Hinmon, D.D (1992): Haematologic effects and feeding performance in cattle fed cull.domestic Allium cepa and Allium sativum. Journal of the American Veterinary Medical Association. 200 (8): 1090 - 1094.

Lu-Yongzhi; Chen-Zhangping; Wu-Xuanjie; Lu - Yz; Chen-ZP; Wu-Xj. (1994): Allitridin analysis by $\mathrm{F} / \mathrm{D} / \mathrm{FPD}$ dual channel gas chromatographic - Science, 32: 2, 61 - 64; 6.

Mehrabian-S; Larry-Yazdy-H; Hayashi-M (ed); Kano-A (ed); Goto-E. (1992): Antimicrobial activity of Alium sativum cepa, Alium porrum (Liliaceae) against enteric pathogens (Entero bacteriacea). International symposium on transplant production systems. Biological, engineering and socioeconomic aspects, Yokohama, Japan, 21-26 July, 1992. Acta Horticulturae. No. 319, 177-182.

Nafady-A.; Abd-EL-Motelib-TY; Salem-B; EL-Zanaty-K. (1990):

Aspergillosis in pigeon and role of thiabendazole or garlic juice for prevention of infection. Assuit - Veterinary - Medical - Journal, 22 : 44, 192 - 197; 13.

Reitman, S. and Frankel, S. (1957): "Colorimetric determination of serum glutamic oxaloacetic and glutamic pyruvic transaminase". Am. J. Clin. Path., $28: 56$ - 58.

Rode-H.; Wet. PM. de; Cywes. S.; De. wet. PM (1989): The antimicrobial effect of Allium sativum L (garlic). South African J. of Sci, 85: 7, $462-464$.

Roy, S.E. (1970): "Colorimetric determination of serum alkaline phosphatase". Clin. Chem., 16: 431.

Sainani, G.S.; Desai, D.B.; Garhe, N.H.; Natu, S.M.; Pise, D.V.,; Sainani; P.G. (1979): Effect of dietary garlic and onion on serum lipid profile in Jain community. Indian J. Med. Res., 69 (5), 776 - 80.

Sharma, K.K. and Sharma, S.P. (1979): Effect of onion and garlic on serum cholesterol on normal subjects. Mediscope, 22 (7), 134 - 6.

Singh-KV; Shukla-N.P (1984): Activity on multiple resistant bacteria of garlic (Allium sativum) extract. Fitoterapia, 55: 5, 313 - 315; 17. Tackholm, V. (1974): "Flora of Egypt" Anglo. Egyptian Bookshop, Cairo, III, $58-112$. 
Teger - Nilson (1961): Determination of serum creatinine. A.C.: Scand. J. Clin. Lab. Invest. 13: 326.

Walters, M. and Gerarde, H. (1970): Determination of total and direct bilirubin". Microchem. J., 15, 231.

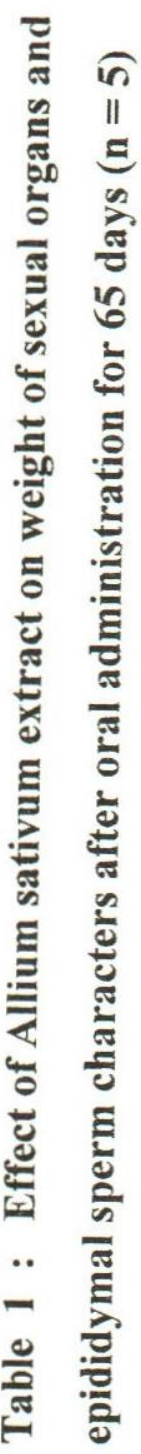

\begin{tabular}{|c|c|c|c|c|c|c|}
\hline \multirow{3}{*}{ 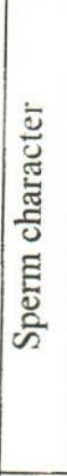 } & 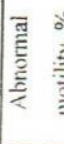 & مْ & $\begin{array}{l}\overrightarrow{0} \\
+1 \\
\dot{\sim}\end{array}$ & & $\stackrel{*}{*} \begin{array}{ll}* & 0 \\
& \stackrel{0}{0}\end{array}$ & $\begin{array}{ll}* & \\
* & \\
+1 & 0 \\
+1 & 0 \\
2 & 0\end{array}$ \\
\hline & ن் & 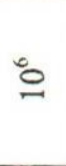 & $\begin{array}{l}\frac{n}{2} \\
+1 \\
\frac{\pi}{6}\end{array}$ & & $\begin{array}{l}0 \\
6 \\
0 \\
x \\
x+1 \\
+1 \\
0 \\
0 \\
0\end{array}$ & 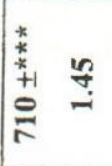 \\
\hline & $\frac{5}{\frac{\pi}{2}}$ & $a^{0}$ & $\begin{array}{l}+1 \\
\stackrel{2}{r}\end{array}$ & ڤొఝ & $\begin{array}{ll}+1 & \infty \\
0 & i\end{array}$ & $\begin{array}{ll}* & n \\
* & 0 \\
+1 & 0 \\
\infty & \vdots\end{array}$ \\
\hline \multirow{4}{*}{ 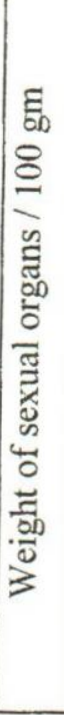 } & 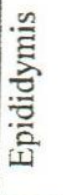 & & \begin{tabular}{l}
+1 \\
$\infty$ \\
$\infty$ \\
\hdashline \\
0
\end{tabular} & $\stackrel{\widetilde{Q}}{\theta}$ & 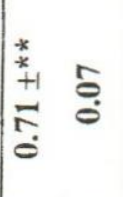 & 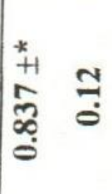 \\
\hline & 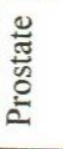 & & $\stackrel{+1}{\stackrel{+}{7}}$ & $\stackrel{m}{\circ}$ & 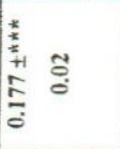 & $\begin{array}{ll}* & \\
+ & \\
+1 & \Xi \\
\infty & \Xi \\
& 0 \\
0 & \end{array}$ \\
\hline & 茎 & $\frac{2}{\frac{0}{0}}$ & $\stackrel{+1}{\stackrel{+1}{6}}$ & $\stackrel{n}{0}$ & 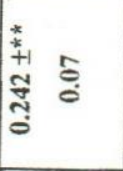 & 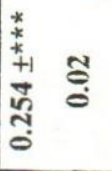 \\
\hline & 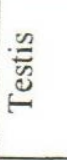 & & & $\hat{\theta}$ & 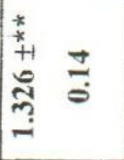 & 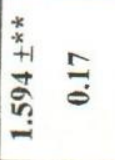 \\
\hline 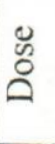 & $\frac{\infty}{ \pm 0}$ & ڤே & & 1 & - ह్రి & ๑̃ ఏ్రి \\
\hline & & 今 & & $v$ & 总 & 氖 \\
\hline
\end{tabular}

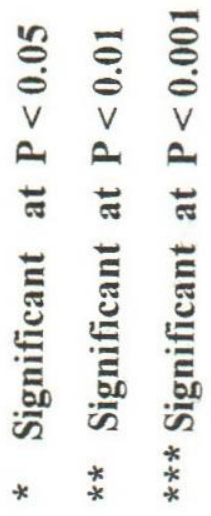


Assiut Vet. Med. J. Vol. 38 No. 76, January 1998

졸

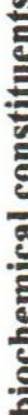

블

ธ

E

E

E

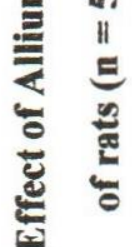

.

N

递

\begin{tabular}{|c|c|c|c|}
\hline 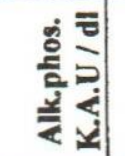 & 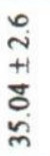 & 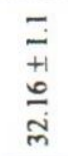 & $\frac{\infty}{+1}$ \\
\hline 논히 & $\begin{array}{l}= \\
+ \\
+1 \\
b \\
\dot{v}\end{array}$ & $\begin{array}{l}\infty \\
0 \\
+1 \\
\infty \\
\sigma \\
\sigma\end{array}$ & $\begin{array}{c}n \\
0 \\
0 \\
+1 \\
\vdots \\
\text { ì }\end{array}$ \\
\hline 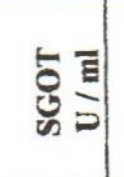 & $\begin{array}{l}\qquad \\
\dot{\sigma} \\
+1 \\
+ \\
\infty\end{array}$ & $\begin{array}{l}\stackrel{+}{\infty} \\
\stackrel{-}{+1} \\
\dot{\infty} \\
\dot{0} \\
0\end{array}$ & 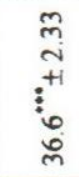 \\
\hline 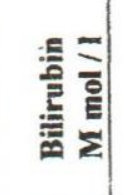 & $\begin{array}{l}a \\
\infty \\
+1 \\
\sim \\
\infty \\
\infty\end{array}$ & 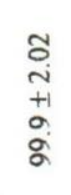 & 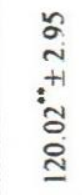 \\
\hline 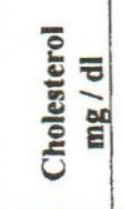 & $\begin{array}{l}8 \\
\text { +1 } \\
+1 \\
\stackrel{2}{2} \\
\frac{1}{a}\end{array}$ & 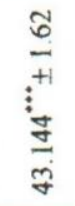 & 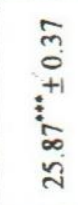 \\
\hline 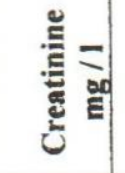 & 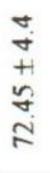 & $\begin{array}{c}n \\
i \\
+1 \\
\frac{+}{2} \\
\infty\end{array}$ & 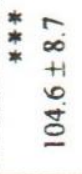 \\
\hline 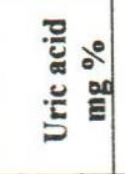 & $\begin{array}{l}\stackrel{\sim}{Z} \\
\stackrel{+1}{N} \\
\stackrel{\sim}{*}\end{array}$ & $\begin{array}{l}8 \\
0 \\
+1 \\
+1 \\
\bar{y}\end{array}$ & 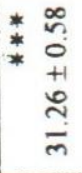 \\
\hline 홈 흠 & 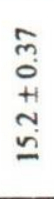 & 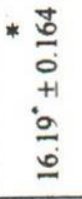 & 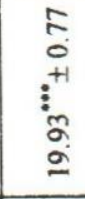 \\
\hline 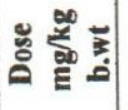 & ' & 임 & ర్లి \\
\hline 4 & c & 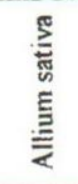 & \\
\hline
\end{tabular}

$\approx \overline{8}$

$\because 0.0$

$\checkmark$ a $a$

a.

ส

荡 震

结 
Assiut Vet. Med. J. Vol. 38 No. 76. Januarv 1998

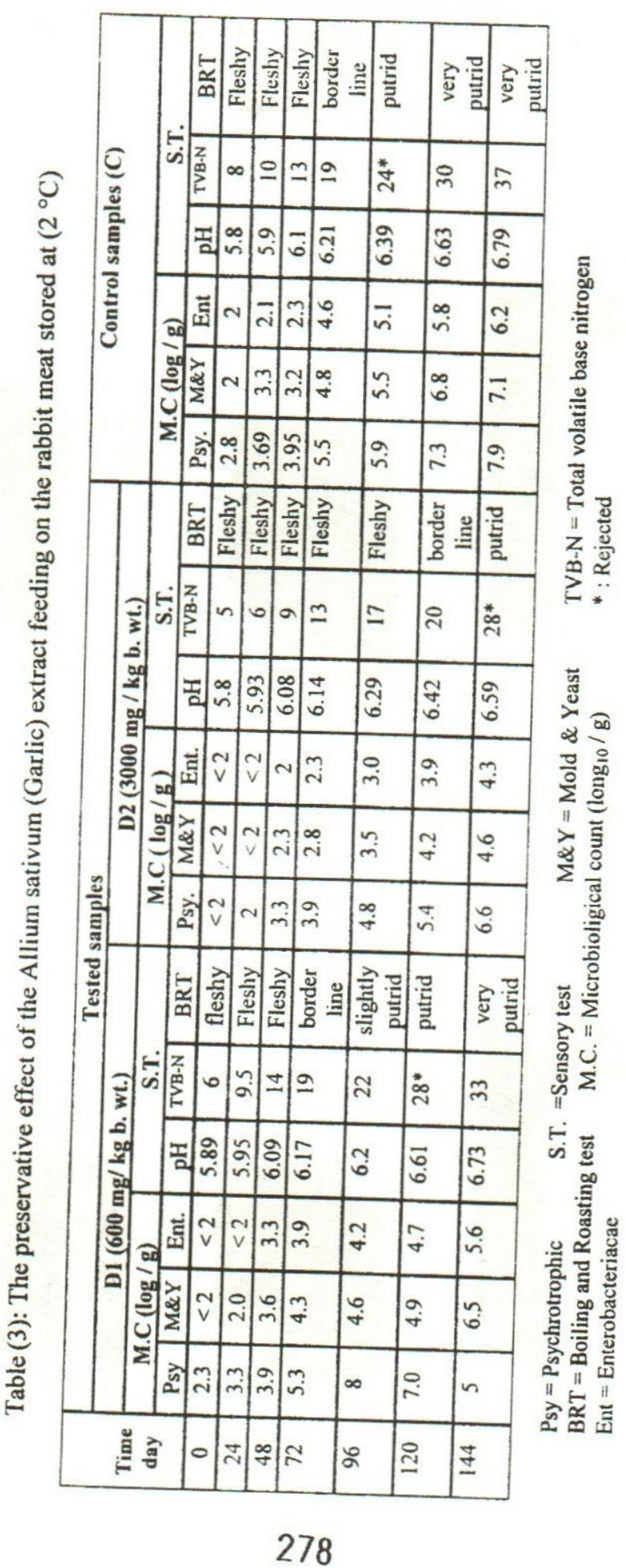


Fig. (1) Systemic antimicarobial effect of Garlic extract on infected surguical wound.

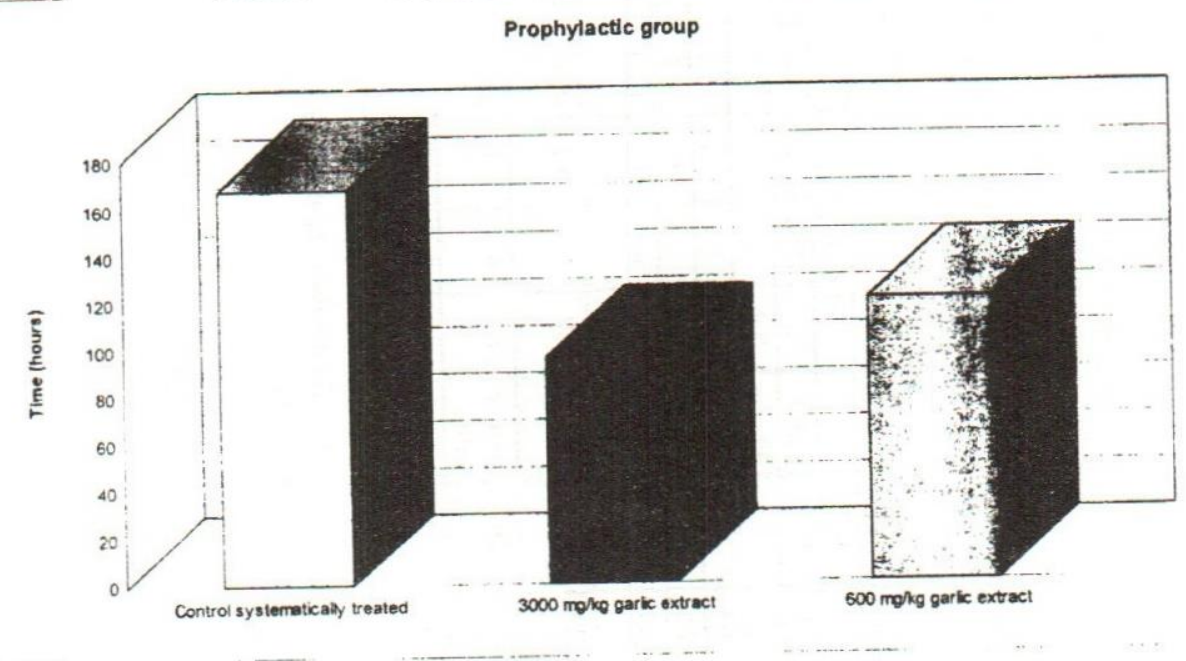

Fig. (2) Local antimicrobial effect of garlic extract

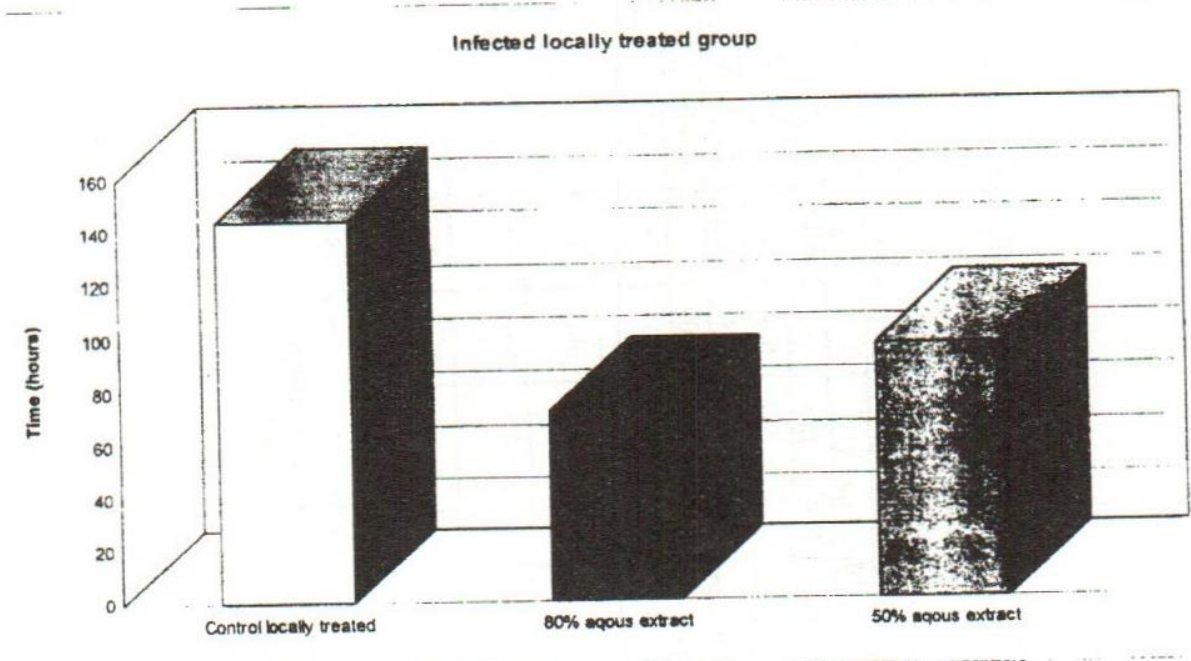


Figs. $(3,4,5)$ : The preservative effect of the Allium sativum (Garlic) extract feeding on the rabbit meat stored at $2^{\circ} \mathrm{C}$.

Fig. 3

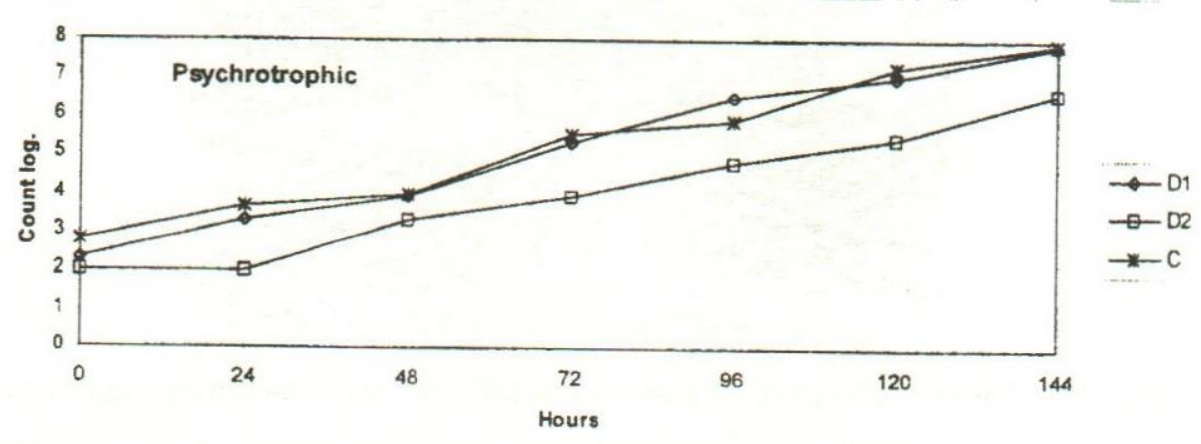

Fig. 4

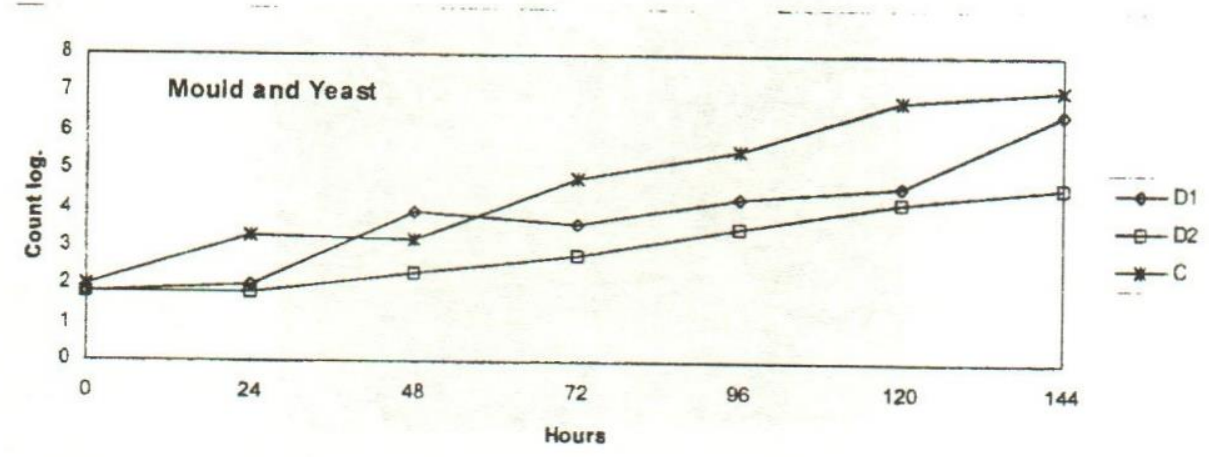

Fig. 5

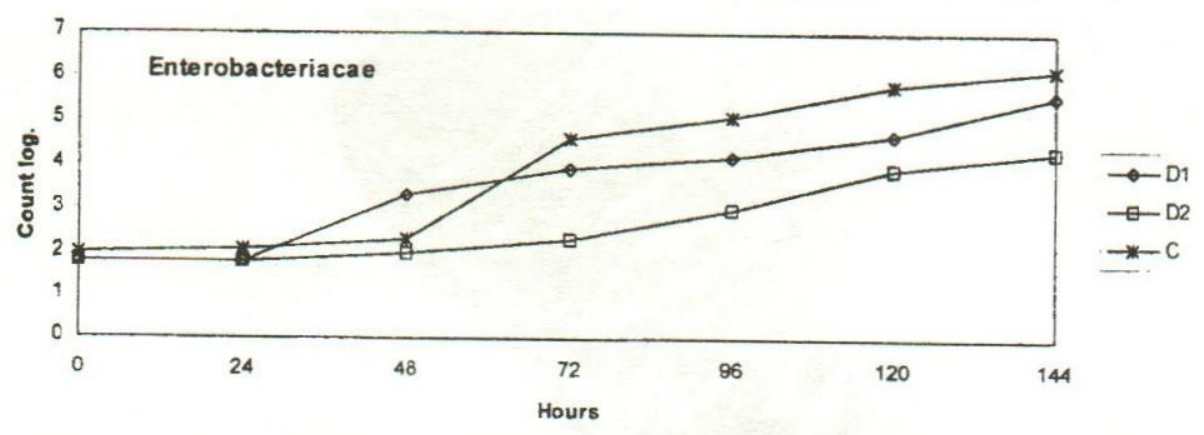


Fig. (6): Liver of group II shows congestion of the vscoulature and granlar degemeration. ( $\mathrm{H} \& \mathrm{E} \quad \mathrm{X} 250$ )

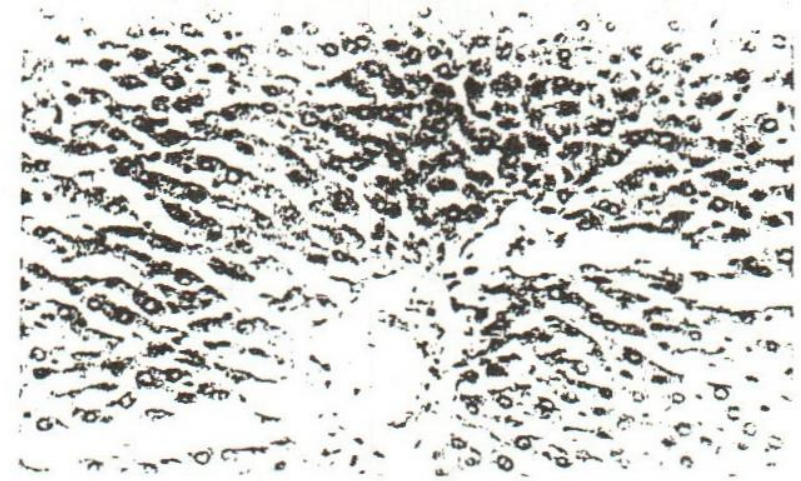

Fig. (7): Kidney of group II shows congestion of the renal blood vessels with interstitial haemorrhage and degeneration of some renal tubules. ( $\mathrm{H} \&$ E X 250).

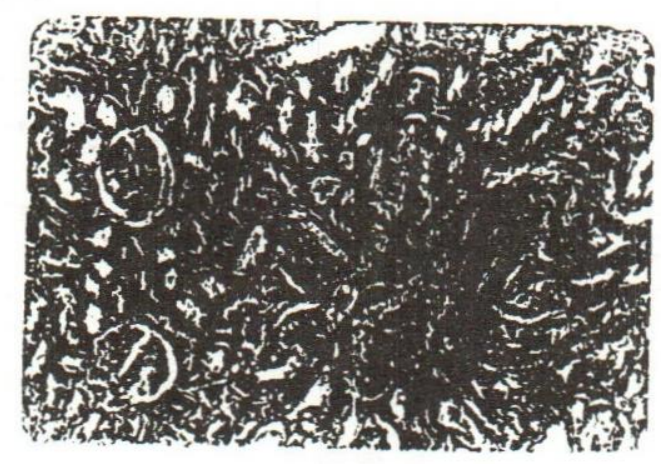

Fig. (8): Intestine of group II shows some degeneration of the lining tubular epithelium. (H \& E X 100)

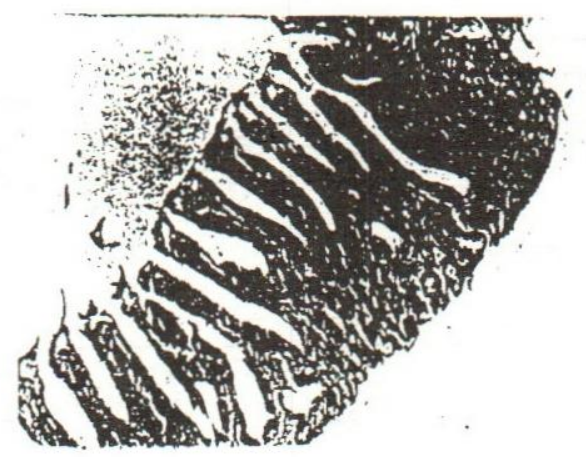

